\title{
Organisational Socialisation Facilitates Overseas Assignment
}

\author{
Pei-Chen (Joy) Lee \\ Cheng-Tai (Roger) Cheng
}

\begin{abstract}
Cross-cultural adjustment is the biggest challenge that derails expatriate success. In responding to the importance of Taiwanese expatriates' adjustment in Mainland China, this study tests, as a critical factor, Socialisation affecting the adjustment of Taiwanese expatriates in Mainland China. As a result, this study critically reviews previous studies on expatriate success, shedding light on key factors in the area of expatriate adjustment and providing multiple guidelines for human resource supervisors and senior executives hoping to ensure expatriate success. The definitions of success and methodological approaches are discussed, and suggestions for improving empirical research in this area are presented. Academic researchers and international enterprises can perhaps clarify whether all international expatriates are affected by the factor as organisational socialisation, and also whether the proposed model can be utilised in studying expatriates in different professional areas from those of this study. Finally, the results and their implications for research and the business world are discussed. This may assist not only Taiwanese MNCs but also global enterprises to perform their international business more efficiently in Mainland China.
\end{abstract}

\section{Keywords}

Taiwanese expatriates, mainland China, socialisation.

\section{Introduction}

As enterprises develop globally, there is a growing challenge to utilise expatriates on international assignments to complete strategically significant tasks (Brewster 1998; Downes and Thomas 1999; Gregersen and Black 1996). Multinational corporations (MNCs) utilise expatriates, not only for reasons of corporate organisation and expertise in critical global markets, but also to smooth the process of entry into new markets or to extend international management abilities (Bird and Dunbar 1991; Boyacigiller 1991; Forster 2000; Rosenzweig 1994; Shaffer, Harrison and Gilley 1999). For that reason, in order to remain competitive in today's international marketplace, enterprises not only acknowledge that transferring competent employees adds crucial skill and knowledge to their overseas performances, enabling them to compete more efficiently in all international positions, but also

Copyright (C) 2008 Victoria University. This document has been published as part of the Journal of Business Systems, Governance and Ethics in both online and print formats. Educational and non-profit institutions are granted a nonexclusive licence to utilise this document in whole or in part for personal or classroom use without fee, provided that correct attribution and citation are made and this copyright statement is reproduced. Any other usage is prohibited without the express permission of the expatriate employees, particularly managerial and professional employees, are vital to the success of overseas assignments such as implementing international corporate tactics and managing and coordinating subsidiaries (Black, Gregersen and Mendenhall 1992). Expatriates are able to play tremendously significant roles during worldwide assignments. Particularly, 
successful expatriate assignments are indispensable to MNCs (multinational corporations) for both developmental and functional reasons (Adler 1983; Brake et al. 1994; Dowling et al. 1998; Mendenhall and Oddou 1985; Stroh and Caligiuri 1998; Tung and Miller 1990).

At present, Mainland China's economic importance to Taiwan is continuing to grow, shown by its ousting of the United States for the first time as Taiwan's largest export market in 2002. Taiwan is also Mainland China's second-largest supplier of imports and the fourth biggest investor in Mainland China, just behind Hong Kong, the U.S. and Japan. Following the rapidly increasing foreign direct investment in Mainland China, an increasing number of expatriates are assigned there. According to that, more and more expatriates are being sent to Mainland China to operate foreign subsidiaries. The Investment Commission of the Ministry of Economic Affairs (ICMEA 2001) estimated that there were over 200,000 populations of Taiwanese expatriates and their families in Mainland China. In the 1980s, only a few Taiwanese employees wanted to be assigned to work in Mainland China, because Mainland China represented a communistic society, with differences in expectations, food, habits, work attitudes, the concept of personal space, etc. to those of most business expatriates. Those factors are often stress producing because they appear to be neither understandable nor ethically acceptable.

In conclusion, investigating the influential factors of expatriate adjustment is significant for several reasons. First, failure of expatriate adjustment may cause premature return from overseas assignments, which may be very costly financially for international enterprises (Coperland and Griggas 1985; Naumann 1992). In addition, non-financial costs of failure, which include damage to the reputation of enterprises, lost business opportunities and lost market or competitive share (Black and Gregersen 1991; Naumann 1992). Second, failure to accomplish the plan of the assignment is as harmful to the expatriate as it is to the parent and host companies. Inability of an expatriate to complete the assignment is likely to damage his or her self-esteem, and self-confidence, and cause a loss of prestige among coworkers (Mendenhall and Oddou 1985; Tung 1987). Third, an unsuccessful period of expatriation is likely to decrease both the subsequent commitment to the parent company (Naumann 1993) and job performance upon repatriation (Adler 1981). Finally, an expatriate failure will have an adverse impact on the decision of qualified expatriates to accept overseas posts (Stroh 1995). Nowadays, despite these negative possibilities, those influential factors still exist, nevertheless, following the increasing investment, many more people volunteer to develop their careers in Mainland China for longer periods. The recent growth of international business has guided enterprises to examine more closely their policies for transferring employees from one country to another (Aryee and Stone 1996; Black, Gregersen and Mendenhall 1992). Without proper international human resource management, the advantages of overseas operations may not be fully realised. Yet in Taiwan, very few studies concerning expatriate problems have been conducted.

\section{Literature Review}

\section{Cross-cultural Adjustment}

The international scope of markets and intensifying global competition are forcing firms to operate in more diverse geographical environments. The ability to establish operations in different locations can allow a firm to more quickly gather technological and market information as well as respond rapidly to local customer demands. This situation often requires the presence of competent overseas expatriates to effectively implement enterprises' strategies. The overseas assignment of executives can thus have a significant impact on an enterprise's success in international markets. As a result, understanding the factors that improve expatriates' adjustment and performance in international environments has become a crucial human resource issue. The original notion of cross-cultural adjustment began from previous work on culture shock. Based on Oberg's (1960) research, 'culture shock' was defined as the phase of anxiety before an individual feels well adjusted in a new culture. Nevertheless, some researchers (as Church 1982; Stening 1979) found that not all expatriates encounter the same degree of anxiety, or experience anxiety for the same duration of time. For that reason, those research results indicated that 
cross-cultural adjustment was an individual difference, which could potentially be forecasted, rather than a constant duration of anxiety that all expatriates would necessarily encounter when they entered a new environment and faced a different culture (Black 1990). For the duration of the process of crosscultural adjustment, uncertainty in the surroundings reduces gradually (Black 1988; Black and Gregersen 1991; Church 1982). The process of cross-cultural adjustment may perhaps be stressful due to the insecurity and ambiguity of not knowing what is appropriate behaviour or actions, coupled with a potential incapability to comprehend feedback from the situation owing to deficiency in knowledge of the language or culture (Black and Gregersen 1991; Louis 1980). Relating to the standard of premature termination of an overseas assignment, expatriates who fail to adjust would be experiencing insuperable stress and would prefer to return to their home country earlier than planned (Tung 1981).

In conclusion, cross-cultural adjustment is defined as the process of adaptation to living and working in a foreign culture. It is the perceived degree of psychological comfort and familiarity an individual has with the new host culture. Current conceptualisations of the construct have focused attention on three specific facets of cross-cultural adjustment. The first facet is work adjustment, which contains adaptation to new job tasks, work roles, and the new work environment. Work adjustment is assisted by similarities in procedures, policies, and task requirements between the parent company and host subsidiary in a foreign country. The second facet is interaction adjustment, which consist of the comfortable accomplishment of interactions with host nationals in both work and non-work situations. Interaction adjustment is the most difficult of the three facets to achieve. The third facet is cross-cultural (general) adjustment, which involves the overall adaptation to living in a foreign culture, and comprises factors such as housing conditions, health care, and cost of living.

\section{Organisational Socialisation}

Organisational socialisation may possibly occur by means of formal organisational schemes and individual efforts that familiarise expatriates with the processes and procedures of the host country organisation. Organisational entry is a critical time for newcomers. A basic premise of organisational socialisation practices is that the nature of a newcomer's initial experiences is imperative to their adjustment to the new environment. Researchers (Chao, et al. 1994; Feldman 1981; Ostroff and Kozlowski 1993) have recognised that typically there are four phases contained in a newcomer's progress. The first phase is concerned with group processes (social integration). In this phase the newcomers are sensitised to the group norms and values, comprehend the relationships between formal and informal work, and discover the person who is most well-informed and influential in the organisation. At the same time newcomers start to recognise how to relate and fit in. The second phase is concerned with task mastery (performance proficiency). The newcomers learn the tasks involved in the job (knowledge, skills, capabilities), important duties, assignments, and priorities. In addition, the newcomers comprehend how to deal with regular problems and how to gain important information in this stage. The third phase is related to work roles (role clarification). The newcomers become acquainted with boundaries of authority, responsibility and appropriate behaviours in this stage. The fourth phase is about organisational attributes (acculturation). In this stage the newcomers achieve an appreciation of the politics, power, goals, and value premises of the organisation; knowledge of the organisation's mission, special languages, key legends, myths, stories, and management's leadership and motivational style. To sum up, organisation socialisation is a procedure through which the individual adjusts to a particular work role in an organisation by learning content and process. Organisation socialisation is also explained as the procedure by which individuals or newcomers gain information concerning routine or desirable behaviours and perspectives within the work surroundings. As a result, in this study it has been speculated that organisational socialisation factor have a significant influence on how individuals, particularly organisation expatriates, adapt themselves to their roles in overseas assignments.

In conclusion, the rationale of organisational socialisation is to comprehend the new environment, thereby reducing the level of uncertainty and offering the expatriate direction concerning what to do and how to perform in an satisfactory manner, given the cultural context of the foreign organisation. On a 
person-to-person basis, interaction with old-timers (mentor programs) facilitates sense-making, situational identification, and acculturation among newcomers (Louis 1980, 1990). Therefore, mentors may accelerate socialisation by providing protégés with information about the internal workings of the organisation and feedback as to appropriate behaviour (Ostroff and Kozlowski 1993). By providing expatriates with access to mentors, MNCs are demonstrating a willingness to support the expatriate during the overseas assignment.

\section{Methodology}

\section{The Research Sample}

The Straits Exchange Foundation of Taiwan was contacted, agreed to support this study and also supplied the addresses of Taiwanese firms established in Mainland China. This organisation was founded in Taiwan on 21 November 1990; it has six units including a secretariat, culture service office, economic and trade service office, traveling service office and service office. Its chief function is to deal with affairs concerning cross-Straits exchanges under the guidance of the 'Mainland Affairs Office'.

According to the list of enterprises supplied by the Straits Exchange Foundation of Taiwan, the target population of this study was 1,786 Taiwanese manufacturing firms located in Shanghai (one city in Mainland China). Shanghai is the most developed city of east Mainland China and many Taiwanese investors set up their manufacturing companies here. With its excellent location, comprehensive transportation network in terms of land, sea and airfreight, together with its huge and high quality pool of human resources, it is no wonder that Shanghai has always been the economic leader, commercial centre and important foreign gateway for the past several centuries. A city with a population of 14 million, Shanghai's total production value is one-sixth of all production of Mainland China.

\section{Sample Size}

Actually, that is hard to find out the real statistics amount about the Taiwanese expatriates work in Mainland China, only the amount of firms located in Mainland China can be found in official statistic of Taiwan Government, therefore, this study adapted the whole Taiwanese firms' amount, instead of whole population number. But this reason should be described and explained in this section. Table 1 presents a helpful lead for calculating the sample size. Tables such as Table 1 can provide a useful guide for determining the sample size. Researchers may need to calculate the necessary sample size for a different combination of levels of precision, confidence, and variability (Israel 1992), by applying an equation such as that proposed by Yamane (1967).

Table 1 Sample size for $\pm 3 \%, \pm 5 \%, \pm 7 \%$ and $\pm 10 \%$ Precision Levels

\begin{tabular}{|c||c|c|c|c||}
\hline \multirow{2}{*}{ Size of Population } & \multicolumn{3}{|c|}{ Sample Size (n) for Precision (e) of: } \\
\cline { 2 - 5 } & $3 \%$ & $5 \%$ & $7 \%$ & $10 \%$ \\
\hline 1,000 & $\mathrm{a}$ & 286 & 169 & 91 \\
\hline \hline 2,000 & 714 & 333 & 185 & 95 \\
\hline \hline 3,000 & 811 & 353 & 191 & 97 \\
\hline \hline 4,000 & 870 & 364 & 194 & 98 \\
\hline \hline 5,000 & 909 & 370 & 196 & 98 \\
\hline \hline
\end{tabular}

Note: $\mathrm{a}=$ Assumption of normal population is poor. The entire population should be sampled. Where Confidence Level is $95 \%$ and $\mathrm{P}=.5$.

Source: Israel (1992) 
Yamane (1967) provided a simplified formula that was also used to calculate sample sizes; the result was similar to Table 5.3.

$$
\begin{gathered}
\frac{\text { Equation: } \mathrm{n}=\mathrm{N} / 1+\mathrm{N}(\mathrm{e})^{2}}{\mathrm{n}=\text { Sample size }} \\
\mathrm{N}=\text { Target population } \\
\text { This Study: } 1786 / 1+1786(0.00212598425) \fallingdotseq 373
\end{gathered}
$$

As a result, the sample size of this study was 400 firms in this study.

There are 20 different categories of industry such as food industry, plastics industry, cement industry, spin and weave, electric machinery, electric equipment included in Taiwanese enterprises located in Shanghai. Twenty Taiwanese companies were selected from each category by using a random numbers table. Therefore, a total of 400 firms was selected from the address book issued by the Straits Exchange Foundation of Taiwan. In this study, the respondents targeted were one expatriate in each firm.

\section{Non-Responses}

A researcher should monitor and minimise the non-responses to avoid bias in the sampling results. In order to avoid bias, in this research the non-responses were managed by sending follow-up mails first. If the participants still did not respond, then the non-responses were managed by replacement.

\section{Response Rate}

The response rate for a mailed questionnaire is the number of questionnaires returned. It is typically expressed as a percentage of the number of subjects selected to participate. The response rate is the single most important indicator of how much confidence can be placed in the results of a survey. A low response rate can be devastating to the reliability of a study. One of the most powerful tools for increasing response is to use follow-ups or reminders. Traditionally, between 10 and 60 percent of those sent questionnaires respond without follow-up reminders. These rates are too low to yield reliable results, so the need to follow up on non-respondents is clear.

In this study, electronic mail was used to increase the response to follow-up attempts by including another copy of the questionnaire.

\section{Research Instrument Reliability}

A test of reliability was conducted on the scales used in the questionnaire. Before conducting consistency estimates of reliability, the reverse-scaled items were reversed. The result of each of the coefficient alphas indicated satisfactory reliability. According to DeVellis Reliability Guidelines (1991), a Cronbach alpha coefficient over 0.7 implies respectable reliability. In this study, Cronbach alpha coefficients of cross-cultural adjustment, and organisation socialisation 0.84387 and 0.85216 respectively. A value of 0.8 is seen as an acceptable value for Cronbanch's alpha; a value substantially lower indicates an unreliable scale. In this study, the Cronbach alpha coefficients of the six scales were over 0.8 that were seen as a good indicator of their reliability and high acceptability.

Table2 Research Instrument Reliability

\begin{tabular}{|l|c|c|}
\hline Variables & Number of Questions & Cronbach $\alpha$ \\
\hline Cross-Cultural Adjustment & 14 & 0.84387 \\
\hline Organisation Socialisation & 14 & 0.85216 \\
\hline
\end{tabular}

\section{Regression Analysis}

A multiple regression analysis was conducted to see how well the proposed model predicted overall cross-cultural adjustment from organisation socialisation. The Table 3 on below demonstrates summary that the linear combination of the proposed model was significantly related to cross-cultural adjustment 
$(\mathrm{F}=92.315, \mathrm{P}$ value $=0.000<0.05)$. The sample correlation coefficient was 0.766 , indicating that approximately 58.7 percent of the variance of the cross-cultural adjustment in the sample can be accounted for by the linear combination of the proposed model. In this study, there was a statistically significant linear relationship between independent variables: organisation socialisation and the dependent variable cross-cultural adjustment. As a result, the proposed model was shown to be statistically significant to cross-cultural adjustment. To sum up, the proposed model unerringly and completely predicts cross-cultural adjustment.

Table3 Regression of Proposed Model Summary

\begin{tabular}{|c|c|c|c|c|c|c|c|c|c|}
\hline Model & $\mathbf{R}$ & $\mathbf{R}^{\mathbf{2}}$ & $\begin{array}{c}\text { Adjusted } \\
\mathbf{R}^{\mathbf{2}}\end{array}$ & $\begin{array}{c}\text { Std. Error of } \\
\text { the Estimate }\end{array}$ & $\begin{array}{c}\mathbf{R}^{\mathbf{2}} \\
\text { Change }\end{array}$ & $\mathbf{F}$ & $\mathbf{d f ~ 1}$ & df 2 & Sig. \\
\hline & 0.766 & 0.587 & 0.580 & 0.6503 & 0.587 & 92.315 & 5 & 325 & 0.000 \\
\hline
\end{tabular}

a. Predictor: (Constant), OSA

\section{Pearson Correlation Coefficient}

This section of the study applied stepwise regression analysis to investigate the influence of organisation socialisation on cross-cultural adjustment. In other words, the predictor that contributed statistically to the prediction of cross-cultural adjustment was included, while those that did not contribute were excluded from the analysis.

Because stepwise regression was requested, SPSS was used to first investigated a model with organisation socialisation, it was a strong correlation on cross-cultural adjustment. The test result, shown in the Table 4, revealed that the partial correlation for organisation socialisation was 0.113 . In effect, the independent variable was significant for explaining the cross-cultural adjustment model.

All the bivariate correlations between organisation socialisation and cross-cultural adjustment were positive. At the same time, each independent variable was statistically significant as revealed in Table 4 below: organisation socialisation $(\mathrm{P}=0.041<0.05)$. This appeared to verify that the practical predictor in this study for cross-cultural adjustment was organisation socialisation. It accounted for organisation socialisation, 14.90 percent $\left(0.386^{2}\right)$ of the variance of cross-cultural adjustment.

Table4 Coefficients of Proposed Model

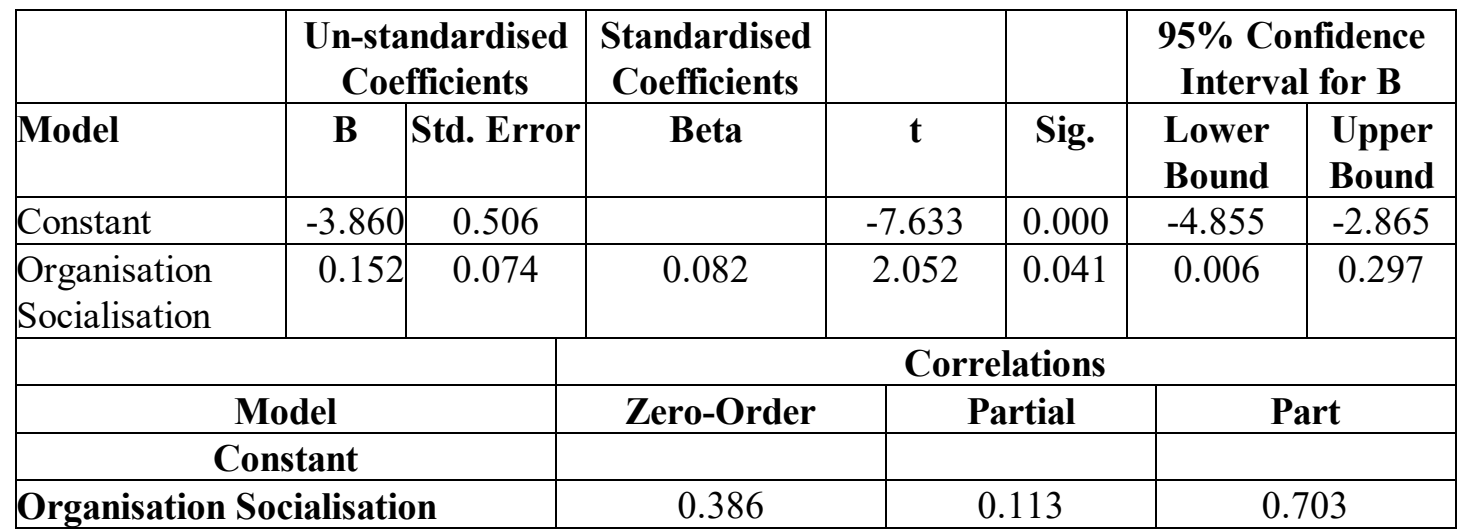

Note: a Dependent Variable: CAA

Correlation coefficients were the statistical method utilised to explore the variable as organisation socialisation and cross-cultural adjustment. The results of the correlation analysis are presented in Table 5 below which shows that the correlations were statistically significant.

The correlation between organisation socialisation and cross-cultural adjustment was also significant, $\mathrm{r}$ $=0.386, \mathrm{P}<0.01$. 
Table 5 Correlations Matrix

\begin{tabular}{|l|l|l|}
\hline & \multicolumn{1}{|c|}{ L.O. } & C.A. \\
\hline Organisation Socialisation & $\mathbf{0 . 1 1 1} *$ & $0.386^{*}$ \\
\hline $\begin{array}{l}\text { Cross-Cultural } \\
\text { Adjustment }\end{array}$ & $\mathbf{0 . 2 0 9 * *}$ & $\mathbf{1 . 0 0 0}$ \\
\hline
\end{tabular}

The previous researcher reviewed the correlation among the variables and concluded that they were associated; therefore, collinear statistics were used. The tolerance for a variable is 1-R squared for the regression of that variable on all the other independents, ignoring the dependent. When tolerance is close to zero, there is high multicollinearity of that variable with other independents and the B and Beta coefficients will be unstable. VIF is the variance inflation factor, which is simply the reciprocal of tolerance. Lower tolerance values indicate that there is a great deal of overlap with other predictors. When VIF is high that means there is high multicollinearity and instability of the B and Beta coefficients. In this study, according to Table 6 , the VIF of organisation socialisation was 1.264,

Table6 Collinearity Statistics

\begin{tabular}{|c|c|c|c|c|c|c|c|}
\hline \multirow[b]{2}{*}{ Model } & \multicolumn{2}{|c|}{$\begin{array}{l}\text { Unstandardised } \\
\text { Coefficients }\end{array}$} & \multirow{2}{*}{\begin{tabular}{|c|}
$\begin{array}{c}\text { Standardised } \\
\text { Coefficients }\end{array}$ \\
Beta \\
\end{tabular}} & \multirow[b]{2}{*}{$\mathbf{t}$} & \multirow[b]{2}{*}{ Sig. } & \multicolumn{2}{|c|}{$\begin{array}{l}\text { Collinearity } \\
\text { Statistics }\end{array}$} \\
\hline & B & Std. Error & & & & Tolerance & VIF \\
\hline Constant & -3.860 & 0.506 & & -7.633 & 0.000 & & \\
\hline O.S. & 0.152 & 0.074 & 0.082 & 2.052 & 0.041 & 0.791 & 1.264 \\
\hline
\end{tabular}

\section{Significance of Independent Variable}

The theoretical and empirical literature on organisational socialisation has mainly focused on the relationship between organisational socialisation tactics and mode of adjustment. This study revealed that the correlation between organisation socialisation and cross-cultural adjustment was positive.

Socialisation is the process by which newcomers learn the behaviours, values, beliefs, and social knowledge needed to accept their new roles and function effectively within the organisation. On the other hand, the socialisation received has been related to various indicators of newcomer adjustment, including role ambiguity, role conflict, stress symptoms, job satisfaction, organisational commitment, organisational identification, and intention to resign.

It is a proven hypothesis that received socialisation in organisations will be positively related to newcomer adjustment. It is essential that international organisations have a sound appreciation of the necessary elements that expatriates need as part of their socialisation process and the impact of these elements on cross-cultural adjustment

\section{Conclusion}

There has recently been a tremendous surge in foreign direct investment in the mainland of the People's Republic of China (PRC), resulting in a substantially increased number of foreign business persons working in Sino-foreign joint ventures, foreign representative offices, foreign wholly owned subsidiaries and branches of foreign firms. Mainland China has developed into an important current and potential market for international business firms. Foreign capital has poured into Mainland China on a large scale over the last two decades and the Chinese market has retained a considerable attraction for international business. In addition, Mainland China has developed into an important destination for foreign investment as the host of a growing multitude of business operations controlled by Taiwanese corporations. Following the phenomenal growth in international trade, globalisation of markets and economic integration are likely to increase the placement of expatriates in foreign assignments. In other words, owing to the rapid globalisation of business and markets, cross-cultural management has 
emerged as a crucial issue for expatriates as well as for international enterprises. The current number of Taiwanese expatriates in Mainland China is uncertain, but in 1994 it was estimated to exceed 100,000. In addition, Investment Commission of the Ministry of Economic Affairs estimated that there were over 200,000 Taiwanese expatriates and their families in Mainland China.

The findings of this study suggest that to achieve the ideal fit between Taiwanese expatriates and the new work and sociocultural environment of Mainland China, both the Taiwanese MNCs and expatriates need to comprehend the influence of factor as organisation socialisation. The majority of the respondents considered that the cross-cultural adjustment of Taiwanese expatriates in Mainland China seems affected by organisation socialisation.

\section{Bibliography}

Allen, N. and Meyer, J. 1993, 'Organizational commitment: evidence of career stage effects?' Journal of Business Research, Vol.26, pp.49-61.

Andreason, A.W., 2003 (Spring), 'Expatriate adjustment to foreign assignments', International Journal of Commerce and Management, Vol.13, No.1, pp.42-53.

Babajeva, E., Romanovska, I. and Allerstorfer, T. Fall 2001, 'Chinese Overseas Networks - Taiwanese FDI into Mainland China', The Chinese Challenge in the $21^{\text {st }}$ Century, CEMS workshop, term paper.

Bandura, A. 1977, Social learning theory, Prentice-Hall Englewood Cliffs, NJ.

Bartol, K.M. 1979, 'Professionalism as a predictor of organizational commitment, role stress, and turnover: a multidimensional approach', Academy of Management Journal, Vol.22, pp.815-821.

Birdseye, M.G. and Hill, J.S. 1995, 'Individual, organizational/work and environmental influences on expatriate turnover tendencies: and empirical study', Journal of International Business Studies, Vol.26, No.4, pp.787-813.

Black, J.S. 1988, 'Work role transitions: a study of American expatriate managers in Japan', Journal of International Business Studies, Vol.19: pp.277-294.

Black, J.S. and Gregersen, H.B. 1991, 'The other half of the picture: Antecedents to cross-cultural adjustment for expatriates in Pacific Rim assignments', Journal of International Business Studies, Vol. 22, No.3, pp.461-477.

Black, J. S., Mendenhall, M.E. and Gregersen, H.B. 1992, Global Assignment: Successfully Expatriating and Repatriating International Managers, Jossey-Bass, San Francisco, CA.

Brett, J.M., Stroh, L.K. and Reilly, A.H. 1990, 'Impact of societal shifts and corporate changes on employee relocation', Employee Relocation Council. Washington, DC.

Caligiuri, P.M., Joshi, A. and Lazarova, M. 1999, 'Factors influencing the adjustment of women on global assignments', International Journal of Human Resource Management, Vol10, No.2, pp.163179.

Chatman, J.A. 1991, 'Matching people and organizations: Selection and socialization in public accounting firms', Administrative Science Quarterly, Vol.36, pp.459-484.

Chautong, N.Y. 2001, 'An excursion into the relationship between Taiwan and China', www.wufi.org.tw.

Chen, M. and Pan, W. 1993, Understanding the Process of Doing Business in China, Taiwan and Hong Kong, Edwin Mellen Press, Lewiston, ME.

Child, J. 2000, 'Management and Organization in China: Key Trends and Issues', In J.T. Li, A.S.

Feldman, D.C. 1981, 'The multiple socialization of organization members', Academy of Management Review, Vol.6, pp.309-319.

Feldman, D.C. and Tommas, D.C. 1992, 'Career management issues facing expatriates', Journal of International Business Studies, Vol.23, No.2, pp.271-292.

Feldman, D.C. and Tompson, H.B. 1993, 'Expatriation, repatriation, and domestic geographical relocation: An empirical investigation of adjustment to new job assignments', Journal of International Business Studies, Vol.23, No.3, pp.507-529. 
Fisher, C. 1986, 'Organizational socialization: An integrative review', Research in Personnel and Human Resource Management, Vol.4, pp.101-145.

Fisher, C.D. and Shaw, J.B. 1994, 'Relocation attitudes and adjustment: A longitudinal study', Journal of Organizational Behavior, Vol.15, pp.209-224.

Fishman, S.R. 1996, 'Developing a global workforce', Canadian Business Review, Vol.23, pp.18-21.

Jones, G.R. 1986, 'Socialization tactics self-efficacy and newcomers' adjustment to organizations', Academy of Management Journal, Vol.29, pp.262-279.

Kanter, R.M., 1977, Work and family in the United States: a critical review and agenda of research policy, Russel Sage Foundation, New York:

Kao, Charng and Chi-Tsung Huang, 1995, 'The Analysis of the Relationship between Taiwan's Investment in Mainland and Cross-Strait Trade', in Kuang-Shen Liao (ed.), The Potential Danger and Opportunity in the Cross-Strait Economic Interaction, Hong Kong University Press, pp. 95120, Hong Kong.

Kao, C. 1992, An empirical study of Taiwan investment on Mainland China, Commonwealth Publishing, Taipei.

Kao, C. 2001, 'The effect on the Taiwanese economy of manufacturing investment in Mainland China in operating locally', Quarterly Publication of Economical Situation and Comment, Vol.7, No.1.

Keeley, S. 1999, 'The theory and practice of localization', in Lee, J., Localization in China: best practice, Euromoney Publications, Hong Kong.

Kim, D.H. 1993, 'The link between individual and organizational learning', Sloan Management Review, pp.37-50.

King, Y.C. 1991, 'Kuan-his and network building: a sociological interpretation', Brown, R., Chinese Business Enterprise: Critical Perspectives on Business and Management, Vol.2, pp.322-357.

Lee, H.W. 2002, A study of Taiwanese banking expatriates in the United States, Published dissertation of University of Idaho.

Markham, W.T., Macken, P.O., Bonjean, C.M. and Corder, J. 1983, 'A note on sex, geographic mobility, and career advancement', Social Forrest, Vol.61, pp. 1138-1146.

Ministry of Economic Affairs (MOEA) (1997), The Investigation Report on the Outward Investment by Manufacturing Industry (in Chinese), Taiwan.

Ministry of Economic Affairs (MOEA) (1998), The Investigation Report on the Outward Investment by Manufacturing Industry (in Chinese).

Ministry of Economic Affairs (MOEA) (1999), 'Table A-12 The Growth Rate of the Industrial Output in Major Countries' (in Chinese), http://www.moea.gov.tw/ meco/stat/four/a-12.htm.

Ministry of Economic Affairs (MOEA) (2000), 'The Role of Service Industry in Economic Development' (in Chinese), http://www.moea.gov.tw/ meco/paper/issue/15.htm.

Ministry of Finance (MoF) (Taiwan) (1993), Report on the Characteristic Classifications of Tradeable Commodities.

Ministry of Finance (MoF) (1998), Monthly Statistics of Exports and Imports, December 1998.

Naumann, E. 1992, 'A conceptual model of expatriate turnover', Journal of International Business Studies, Vol.23, No.2, pp.499-531.

Naumann, E. 1993, 'Antecedents and consequences of satisfaction and commitment among expatriate managers', Group and Organization Management, Vol.18, No.2, pp.153-187.

Naumann, E. 1993, 'Organisational predictors of expatriate job satisfaction', Journal of International Business Studies, Vol.10, No.1, pp.61-80.

Odom, R.Y., Boxx, W.R. and Dunn, M.G. 1990, 'Organizational cultures, commitment, satisfaction, and cohesion', Public Productivity and Management Review, Vol.14, pp.157-168.

Ondrack, D. 1985, 'International Transfers of Managers in North American and European MNEs', Journal of International Business Studies, Vol.16, pp.1-19.

Ostroff, C. and Kozlowski, S.W.J. 1993, 'The role of mentoring in the information gathering processes of newcomers during early organizational socialization', Journal of Vocational Behavior, Vol.42, pp.170-173.

Redding, S.G. 1982, 'Cultural effects on the marketing process in Southeast Asia', Journal of the Market Research Society, Vol.24, No.2, pp.98-114. 
Schak, D.C. 1997, 'Taiwanese labour management in China', Vol.19, No.4, pp.365-373.

Schneider, S.C. and Asakawa, K. 1995, 'American and Japanese expatriate adjustment: a psychoanalytic perspective', Human Relations, Vol.48, pp.1109-1127.

Selmer, J. 2002, 'Practice makes perfect? International experience and expatriate adjustment', Management International Review, Vol.42, No.1, pp.71-88.

Seo, K.K. 1993, 'Economic Reform and Foreign Direct Investment in China before and after the Tiananmen Square Tragedy', In Lane Kelley and Oded Shenkar, (eds), International Business in China, Routledge, New York.

Sergeant, A. and Frenkel, S. 1998, 'Managing people in China: perceptions of expatriate managers', Journal of World Business, Vol.33, No.1, pp.17-34.

Testa, M.R. 2001, 'Organizational commitment, job satisfaction, and effort in the service environment', The Journal of Psychology, Vol.15, No.2, pp.226-236.

Torbion, I. 1982, Living Abroad, Wiley, New York, NY.

Torbion, I. 1994, 'Operative and strategic use of expatriates in new organizations and market structures', International Studies of Management and Organization, Vol.24, No.3, pp.5-17.

Yavas, U. and Bodur, M. 1999, 'Satisfaction among expatriate managers: correlates and consequences, Career Development International, Vol.4, No.5, pp.261-269.

Yavas, U., Luqmani, M. and Quraeshi, Z. 1990. 'Organizational commitment, job satisfaction, work values: Saudi and expatriate managers', Leadership and Organizational Development Journal, Vol.11, No.7, pp.3-10.

Ying, Y.W., 1996, 'Immigration satisfaction of Chinese Americans: An empirical examination', Journal of Community Psychology, Vol.24, pp.3-15. 